\title{
A review of total volume environment and individually controlled micro-environment
}

\author{
Weixin Zhao*, Risto Kosonen, Simo Kilpeläinen, and Sami Lestinen \\ Aalto University, Espoo, Finland
}

\begin{abstract}
Indoor environment has great effects on the health, comfort, and performance of occupants in modern buildings. The energy used for ventilating of buildings is substantial. However, ventilation based on total volume air distribution in spaces is not always an energy efficient way to provide high-quality indoor environments. Recently, individually controlled ventilation, which is designed to supply clean air where, when, and as much as needed, makes it possible to efficiently achieve high-quality indoor environment while reducing energy use. The personalized solutions generate a micro-environment that covers the space where the user spends a relatively long time. This review based on a number of experimental and numerical studies on total volume ventilation, zonal ventilation and personalized ventilation to assess the most suitable methods for indoor environment. Performance in terms of thermal comfort, air quality and energy efficiency are examined. In this study, different ventilation systems are classified according to specific requirements and assessment procedures. Finally, a discussion on the application and benefits of these ventilation is conducted and gives a direction for further investigation. The analysis results form a basic framework regarding the application of personalized ventilation in future.
\end{abstract}

\section{Introduction}

The traditional HVAC system aims to create uniform conditions in the entire conditioned space. It has been generally assumed that providing indoor environment preferred by an "average" person ensures the best thermal comfort 1 . There is potentially, however, a controversy between the need to provide better indoor environment and to reduce energy consumption for buildings ventilation. The ideal solution for this situation could be to improve indoor environment with energy-efficient ventilation design.

Advanced ventilating methods and new solutions based on heat, contaminant, and air distribution control are urgently required. Today's centralized heating, ventilating, and air-conditioning (HVAC) systems must be replaced with decentralized room systems, personalized micro-environmental systems attached to furniture. Providing each occupant with active control over micro-environment is an important new principle that will make it possible to achieve much higher levels of indoor environmental quality. Therefore, research on implementation and operation of the individually controlled micro-environment in general, in buildings is important.

The European guidelines define three categories of indoor environment 2. It suggests that the highest quality of indoor environment, Category A, may require individual control of the micro-environment of each occupant in a space. ASHRAE standard 55 (2004) also suggests individually controlled under some conditions 3 . In this case, personalized ventilation can be applied, which aims to condition only a relatively small space around the occupant in contrast to the traditional HVAC systems. Recently, different personalized conditioning systems have been introduced, including personalized ventilation 4 , a combination of personalized ventilation with local convective and radiant heating 5, 6, a personal environmental module 7 , or even a phase change material cooling vest 8 . It has been shown that these systems improve an individual's comfort and reduce the energy consumption when designed and used properly 48 .

\section{Total volume ventilation}

\subsection{MV and DV}

The mixing ventilation (MV) and displacement ventilation (DV) are two major total volume ventilation methods that have been widely studied.

The use of mixing ventilation has been well defined in various international standards regarding thermal comfort and indoor air quality 2, 9,10. Recently, the design and application of MV was already systematically illustrated by Dirk Muller 10. The principle behind a MV system is to dilute the contaminated room air by mixing the

\footnotetext{
* Corresponding author: weixin.zhao@aalto.fi
} 
supplied fresh air with indoor air to lower the contaminant concentrations, as shown in Fig.1 a).

DV is based on the principle of displacing contaminated room air with fresh air from outside, as shown in Fig. 1b) 12. The most common method to calculate airflow rates with DV is the temperature-based method. Cool air is normally supplied at low velocity (typically $<0.5 \mathrm{~m} / \mathrm{s}$ ) at or near the floor to create an upward air movement (thermal plumes) as it is warmed up by heat sources in the room. This will normally create vertical gradients of air velocity, temperature and contaminant concentration.

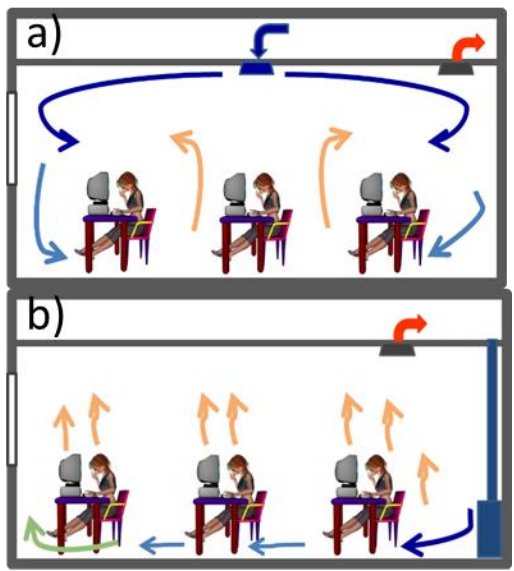

Fig. 1. a) mixing ventilation and b) displacement ventiation

Comparison with MV, DV can maintain a better IAQ, especially for breathing zone. The results show that the air is younger at breathing zone for DV than that of MV. And $\mathrm{CO}_{2}$ generated by the occupants is also easier to be expelled in the DV cases. The workshop with high cooling load would require a high ventilation rate. For DV, high cooling load requires much higher air recirculation than that for conventional MV in order to maintain thermal comfort. In practice, it is not appropriate to apply DV for spaces with excessive cooling load 13 . The air velocity of $\mathrm{DV}$ is smaller than $0.2 \mathrm{~m} / \mathrm{s}$. The temperature difference between the head and foot level of a sedentary occupant is less than $3 \mathrm{~K}$. The percentage of dissatisfied people due to draft $(\mathrm{PD})$ is $10 \%$ and the predicted percentage of dissatisfied is less than $20 \%$. The result shows that besides being not energy-efficient and being not cost-efficient, a high ventilation rate might also have adverse effect on thermal comfort 14 .

\section{$2.2 \mathrm{SV}$}

Stratum ventilation (SV) supplies conditioned air horizontally to the breathing zone, forming a sandwich shape vertical air temperature profile with the lowest value at the head level, as shown in Fig. 2.

Because the supply air enters the breathing zone directly, the supply air path is shorten. Therefore, the mean age of air is younger, the ventilation effectiveness is higher and indoor air quality is better in the breathing zone. The particle concentrations for the entire room and for the breathing zone under stratum ventilation were less than that under displacement ventilation.

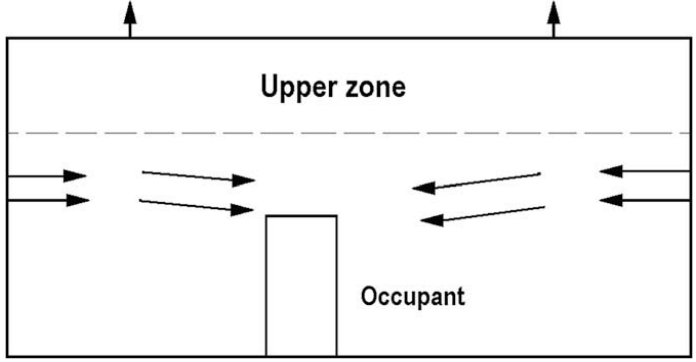

Fig. 2. Conceptual diagrams of stratum ventilation [19].

However, the deposited particle mass on room walls and furniture surfaces under stratum ventilation was bigger than that under displacement ventilation 15. Tian et al. found the inhaled air quality for the occupant improved when supply air temperature increased from 19 to $21^{\circ} \mathrm{C}$ by numerical method and experimental test 16 . He also showed that the ventilation effectiveness is close to 1.5. Hence, this ventilation method could therefore be expected to provide satisfactory indoor air quality in an energy-efficient way 17.

Fong et al. indicated that stratum ventilation could provide a satisfying level of thermal comfort even when the room temperature is up to $27^{\circ} \mathrm{C}$ using human test subjects 18. Computational results also show that stratum ventilation has the potential to maintain better thermal comfort with a smaller temperature difference between the head and foot level 15. Cheng et al. found air velocity and temperature in the occupied zone are reasonably uniform by adjusting room temperature, supply airflow rate and supply terminal type. The requirement of an air diffuser performance index (ADPI) of at least $80 \%$ was achieved for most cases. Subjective assessments using the ASHRAE 7-point scale indicate that thermal sensations of subjects in stratum ventilation are also uniform 19. It was found that the room temperature had a great impact on the overall thermal sensation, local thermal sensation and draft. Increasing the supply airflow rate from $7 \mathrm{ACH}$ to $17 \mathrm{ACH}$, only exhibited a small influence on the thermal sensation and draft, indicating a preference for more air movement. More than $80 \%$ subjects felt comfortable under the neutral temperature of $27^{\circ} \mathrm{C}$. However, to minimize draft complaints, the supply air temperature should not be below $20^{\circ} \mathrm{C} 20$.

Lin et al. summarizes the year-round-totaled energy consumption for the various cases investigated without part-load control. The percentage primary energy saving is $44 \%$ with the use of stratum ventilation when compared with mixing ventilation. With a higher fresh air ratio like the classroom, the percentage energy saving can be even up to $74 \%$ for stratum ventilation 21 . Lee et al. found that the year round energy saving was also substantial, typically around $20 \%$ and $40 \%$, when compared with displacement ventilation and mixing ventilation, respectively 22 .

\section{Individually controlled micro- environment}


The term "human micro-environment" was related to the environment in the vicinity of the human body 23,24 . The characteristics of the micro-environment depend on the interaction of its parts and on several factors, such as the uniformity of the surrounding environment, the posture of the body, its movement and contact with surfaces (e.g. furniture), clothing design, conditions at the skin, and the impact of external factors (air movement, thermal radiation, etc.). Therefore, the micro-environment is not uniformly distributed over the body and that it changes over time.

Melikov investigated the micro-environment around a human body, and especially on its interaction with the surrounding environment. The free convection flow generated by a human body (including the convective boundary layer around the body and the thermal plume above the body), its interaction with external invading flows and the resulting heat and mass transfer is included, all of which are important for thermal comfort and inhaled air quality 25. Experimental researches on air flow distribution close to human body, convective and radiative heat transfer from human body to the surrounding environment have been carried out 2630 .

During the last few years, CFD technology has progressed and made it possible to analyze the micro-environment around human body. A growing number of computational thermal manikins have been proposed with the purpose of determining parameters that are not able, at least very difficult, to be obtained from experiment or making a comparison with experiment results 3134 .

\subsection{POV}

The protected occupied zone ventilation (POV) was defined by using a low turbulent plane jet to separate an office environment into several subzones, as shown in Fig. 3 35. Hence, POV can be applied in a protected occupied zone.

Unlike traditional ventilation systems, which are based on total volume airflow method, the principle of POV is to separate an internal space into different personal work areas or subzones using downward plane jets. POV may be employed to reduce the exposure of people in a protected zone from indoor pollutants emitted in a source zone. The protecting effect of the POV system is attributable the disruption of the direct exhalation flow in the micro-environment around the two manikins. The local micro-environment created around the manikins with the downward plane jet was observed and no collision of the rising thermal plume and the plane jet was found 36 .

The capacity of a POV system to separate the room into two zones with different concentration levels of contaminant indicates that the POV may protect people from infection of epidemic respiratory disease via a crosscontaminant inside a room. The findings have shown that a POV may reduce the risk of exposure to indoor gaseous pollutants emitted in the source zone 37-39.
It was found that the protection efficiency of the POV varies from $8 \%$ to $50 \%$ depending on the supply air velocity, the location of exhaust and the use of a partition 35 .

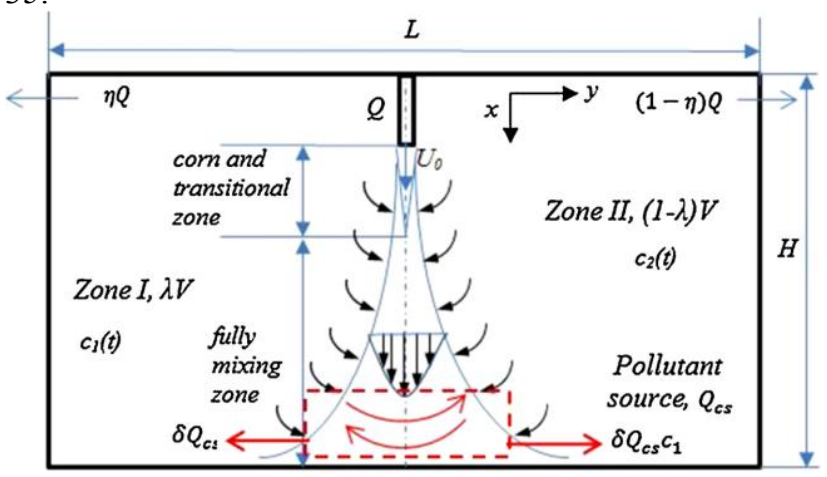

Fig. 3. Protected occupied zone ventilation [35].

\subsection{PV}

Personalized ventilation (PV) aims at supplying highquality air directly to the exposure region, as shown in Fig. 4. During the last two decades, many studies have performed to improve the air quality of a person's working environment via personalized ventilation 40-51.

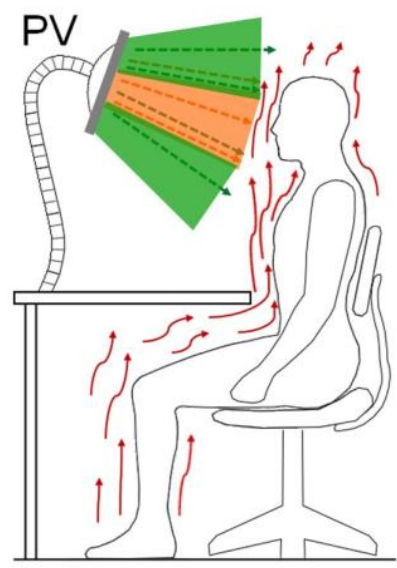

Fig. 4. Personalized ventilation.

The clean air supplied far from the occupants is more or less polluted and warm by the time it is inhaled with total volume ventilation. The improvements of air quality by personalized ventilation are well documented by a number of studies using a thermal manikin 51-57 as well as human subjects $51,58-65$. The highest quality of inhaled air can be achieved when the flow of clean and cool personalized air penetrates the free convection flow and reaches an occupant's face unmixed with the surrounding polluted room air. PV air supplied at a low turbulence level has resulted in better perceived air quality 47. Physical measurements identify a significant decrease of pollution concentration in inhaled air with PV in comparison with traditional ventilation 40, 66-74. The amount of inhaled clean personalized air has been shown to depend on the design of the ATD and its positioning in regard to the occupant. The flow rate (typically from less than $5 \mathrm{l} / \mathrm{s}$ up to $20 \mathrm{l} / \mathrm{s}$ ) and the direction of the personalized airflow, as well as the difference between the room air and 
the PV airflow temperature, size of target area also influence 50, 55. By using PV, the percentage dissatisfied with air quality, 3 min after initial occupancy, decreased from $22 \%$ with MV to $7 \%$ with PV 58 .

In rooms with mixing ventilation, the use of PV will always protect the occupants from airborne transmission of infectious agents and will be superior to mixing ventilation alone 69. Khalifa et al. investigated how to use PV to reduce the mixing processes by the personal ventilation jet 75 . In rooms with displacement ventilation, however, PV promotes mixing of the exhaled air with room air 69,73 . A similar effect may occur in rooms with underfloor ventilation 71-73. Therefore, in order to keep an acceptable background environment, total volume ventilation in combination with PV can best be applied in rooms with high heat and/or pollution loads.

Substantial potential of PV for improvement of occupants' thermal comfort has been measured as well 43 , 58, 75-80. The acceptability of the thermal environment with PV compared with without PV significantly improves at room temperature above $23^{\circ} \mathrm{C}$. Control over supplied airflow rate, i.e., local air velocity, obviously makes it possible to avoid draught discomfort. It has been documented that PV improves occupants' thermal comfort, especially in warm environments [80, 81]. The thermal comfort level can also be improved by using PV. The Predicted Percentage of Dissatisfied (PPD) reduce from $27 \%$ (without personalized ventilation) to $16 \%$ (with personalized ventilation) 52 .

A chair equipped with fans to enhance the convective plume has been investigated in conjunction with displacement ventilation by Sun et al. 82. Even a personalized cooling system incorporated in the clothing has been recently tested. A vest equipped with phase change material improved thermal comfort at rather extreme temperatures, which can occur in the office environment during summer heat waves 83 . Faulkner et al. designed a task ventilation system with an air supply nozzle located underneath the front edge of a desk and measured air change effectiveness ranged from 1.4 to 2.7 , which higher than conventional ventilation 84 .

Table 1. Performance of different ventilation compared with mixing ventilation and typical applications

\begin{tabular}{|c|c|c|c|l|}
\hline DV & $\begin{array}{c}\text { Indoor } \\
\text { air } \\
\text { quality }\end{array}$ & $\begin{array}{c}\text { Thermal } \\
\text { comfort }\end{array}$ & $\begin{array}{c}\text { Energy } \\
\text { benefit }\end{array}$ & Application \\
\hline++ & - & ++ & $\begin{array}{l}\text { high ceiling } \\
\text { height, high } \\
\text { density of } \\
\text { persons and lot } \\
\text { of contaminants }\end{array}$ \\
\hline SV & ++ & ++ & + & $\begin{array}{l}\text { class room type } \\
\text { of space }\end{array}$ \\
\hline POV & ++ & - & - & $\begin{array}{l}\text { places to protect } \\
\text { spreading of } \\
\text { contaminants }\end{array}$ \\
\hline PV & +++ & +++ & +++ & $\begin{array}{l}\text { workplaces for } \\
\text { personal control }\end{array}$ \\
\hline
\end{tabular}

The summary shows that up to $80 \%$ of inhaled air could consist of fresh personalized air with a supply flow rate of less than $3.0 \mathrm{l} / \mathrm{s} 85$. In addition, it was shown that personalized ventilation can save up to $60 \%$ and $51 \%$ of energy compared with mixing ventilation in cold and hot climates, respectively 86,87 . Some studies shown the improvement in work performance and inhaled air quality by DV and PV, with saving of about $20 \%$ energy $40,48$.

Furthermore, PV combined with a passive chilled beam my save up to $80 \%$ of the ventilation air compared to mixing ventilation alone 87 . PV used to supply clean out door air to each desk combined with a separate background mixing ventilation system that is used to condition and recirculate the room air has been shown to be a promising strategy that leads to improved indoor environmental quality at the desk and up to $50 \%$ energy saving compared to mixing ventilation alone 87 .

\section{Discussion and conclusion}

As shown in Table 1, there are three indices that can be used to assess the performance of a ventilation system regarding indoor air quality, thermal comfort and energy efficiency. In addition, the performance of different ventilation systems will be determined by their specific tasks and such systems could also be assessed by different indices.

In practice, the individual differences, based on factors such as age, gender, clothing, activity, or body mass, make it impossible to satisfy the comfort need so fall the occupants using a total volume conditioning 88. Present total volume air distribution principles are inefficient because it does not account for individual differences between occupants and provides only limited or no personal control at all over their microenvironment. Thus, total-volume ventilation has limitations and is often unable to provide each occupant simultaneously with high level of thermal comfort and air quality.

Energy saving potential of using different ventilation methods should be evaluated by taking into account comprehensive conditions in the space, i.e. work performance, inhaled air quality, thermal comfort. The combination of different types of ventilation, like DV and $\mathrm{MV}, \mathrm{PV}$ and DV, might have a better performance than using only one method.

\section{Reference}

1. De Dear, R. (2011). Revisiting an old hypothesis of human thermal perception: alliesthesia. Building Research \& Information, 39(2), 108-117.

2. CEN, C. (1752). Ventilation for Buildings: Design Criteria for the Indoor Environment 1998.

3. Standard, A. S. H. R. A. E. (2004). Standard 55-2004. Thermal environmental conditions for human occupancy, 9-11. 
4. Melikov, A. K. (2004), Personalized ventilation. Indoor Air, 14: 157-167.

5. Melikov, A. K., \& Knudsen, G. L. (2007). Human response to an individually controlled microenvironment. HVAC\&R Research, 13(4), 645660.

6. Watanabe, S., Melikov, A. K., \& Knudsen, G. L. (2010). Design of an individually controlled system for an optimal thermal microenvironment. Building and Environment, 45(3), 549-558.

7. Demeter, M. G., Wichman, P. E., Endres, L. S., \& Rohrer, C. E. (1989). U.S. Patent No. 4,872,397. Washington, DC: U.S. Patent and Trademark Office.

8. Gao, C., Kuklane, K., Wang, F., \& Holmér, I. (2012). Personal cooling with phase change materials to improve thermal comfort from a heat wave perspective. Indoor air, 22(6), 523-530.

9. Comite'Europe'en de Normalisation, C. E. N. (2007). Indoor environmental input parameters for design and assessment of energy performance of buildings addressing indoor air quality, thermal environment, lighting and acoustics. EN 15251.

10. International Organization for Standardization. (2005). Ergonomics of the thermal environment: analytical determination and interpretation of thermal comfort using calculation of the PMV and PPD indices and local thermal comfort criteria. International Organization for Standardization.

11. Müller, D., Kandzia, C., Kosonen, R., Melikov, A. K., \& Nielsen, P. V. (2013). Mixing VentilationGuide on mixing air distribution design, REHVA Guidebook No 19. Brussels: Federation of European Heating, Ventilation and Air Conditioning Associations Khalifa, H. E., Janos, M. I., \& Dannenhoffer III, J. F. (2009). Experimental investigation of reduced-mixing personal ventilation jets. Building and Environment, 44(8), 1551-1558.

12. Yuan, X., Chen, Q., \& Glicksman, L. R. (1998). A critical review of displacement ventilation. ASHRAE transactions, 104, 78.Lee, C. K., Fong, K. F., Lin, Z., \& Chow, T. T. (2013). Year-round energy saving potential of stratum ventilated classrooms with temperature and humidity control. HVAC\&R Research, 19(8), 986-991.

13. Lin, Z., Chow, T. T., Fong, K. F., Tsang, C. F., \& Wang, Q. (2005). Comparison of performances of displacement and mixing ventilations. Part II: indoor air quality. International journal of refrigeration, 28(2), 288-305.

14. Lin, Z., Chow, T. T., Fong, K. F., Wang, Q., \& Li, Y. (2005). Comparison of performances of displacement and mixing ventilations. Part I: thermal comfort. International journal of refrigeration, 28(2), 276-287.

15. Lin, Z., Chow, T. T., Tsang, C. F., Fong, K. F., \& Chan, L. S. (2009). Stratum ventilation-a potential solution to elevated indoor temperatures. Building and Environment, 44(11), 2256-2269.
16. Tian, L., Lin, Z., Liu, J., Yao, T., \& Wang, Q. (2011). The impact of temperature on mean local air age and thermal comfort in a stratum ventilated office. Building and environment, 46(2), 501-510.

17. Tian, L., Lin, Z., \& Wang, Q. (2011). Experimental investigation of thermal and ventilation performances of stratum ventilation. Building and Environment, 46(6), 1309-1320.

18. Fong, M. L., Lin, Z., Fong, K. F., Chow, T. T., \& Yao, T. (2011). Evaluation of thermal comfort conditions in a classroom with three ventilation methods. Indoor Air, 21(3), 231-239.

19. Cheng, Y., Fong, M. L., Yao, T., Lin, Z., \& Fong, K. F. (2014). Uniformity of stratum-ventilated thermal environment and thermal sensation. Indoor Air, 24(5), 521-532.

20. Cheng, Y., Lin, Z., \& Fong, A. M. (2015). Effects of temperature and supply airflow rate on thermal comfort in a stratum-ventilated room. Building and Environment, 92, 269-277.

21. Lin, Z., Lee, C. K., Fong, S., Chow, T. T., Yao, T., \& Chan, A. L. S. (2011). Comparison of annual energy performances with different ventilation methods for cooling. Energy and Buildings, 43(1), 130-136.

22. Cao, G., Sirén, K., \& Kilpeläinen, S. (2014). Modelling and experimental study of performance of the protected occupied zone ventilation. Energy and Buildings, 68, 515-531.

23. Lewis, H. E., Foster, A. R., Mullan, B. J., Cox, R. N., \& Clark, R. P. (1969). Aerodynamics of the human microenvironment. The Lancet, 293(7609), 12731277.

24. Clark, R. P., \& Toy, N. (1975). Forced convection around the human head. The Journal of physiology, 244(2), 295-302.

25. Melikov, A. K. (2015). Human body microenvironment: The benefits of controlling airflow interaction. Building and Environment, 91, 70-77.

26. Chang, S. K. W., \& Gonzalez, R. R. (1993). Air velocity profiles around the human body. TRANSACTIONS-AMERICAN SOCIETY OF HEATING REFRIGERATING AND AIR CONDITIONING ENGINEERS, 99, 450-450.

27. Homma, H. (1988). Examination of free convection around occupant's body caused by its metabolic heat. ASHRAE Transactions, 94(1), 104-124.

28. Myers, J. B., Hosni, M. H., Jones, B. W., \& Melikov, A. (1998). Interaction of air motion with the human body/Discussion. ASHRAE Transactions, 104, 863.

29. Gan, G. (1994). Numerical method for a full assessment of indoor thermal comfort. Indoor Air, 4(3), 154-168.

30. Kato, S. (1996). Numerical analysis of contaminant distribution around a human body. Roomvent'96, 7, 2, 129-136.

31. Chang, S. K., \& Gonzalez, R. R. (1989). Air velocity mapping of environmental test chambers (No. 
USARIEM-M65-89). ARMY RESEARCH INST OF ENVIRONMENTAL MEDICINE NATICK MA.

32. Brohus, H. (1997). Personal exposure to contaminant sources in ventilated rooms (Doctoral dissertation, Department of Building Technology and Structural Engineering, Aalborg University).

33. Hyun, S., \& Kleinstreuer, C. (2001). Numerical simulation of mixed convection heat and mass transfer in a human inhalation test chamber. International journal of heat and mass transfer, 44(12), 2247-2260

34. Hayashi, T., Murakami, S., Kato, S., \& Jeong-Hoon, Y. (2002). CFD analysis on rising stream around a human body and its effect on inhalation air quality. ASHRAE Transactions, 108, 1173.

35. Cao, G., Nielsen, P. V., Jensen, R. L., Heiselberg, P., Liu, L., \& Heikkinen, J. (2015). Protected zone ventilation and reduced personal exposure to airborne cross-infection. Indoor Air, 25(3), 307-319.

36. Melikov, A. K., Cermak, R., \& Majer, M. (2002). Personalized ventilation: evaluation of different air terminal devices. Energy and buildings, 34(8), 829836.

37. Cao, G., Sirén, K., \& Kilpeläinen, S. (2014). Modelling and experimental study of performance of the protected occupied zone ventilation. Energy and Buildings, 68, 515-531.

38. Cao, G., Nielsen, P. V., Jensen, R. L., Heiselberg, P., Liu, L., \& Heikkinen, J. (2015). Protected zone ventilation and reduced personal exposure to airborne cross-infection. Indoor Air, 25(3), 307-319.

39. Cao, G., Sirén, K., \& Kilpeläinen, S. (2014). Modelling and experimental study of performance of the protected occupied zone ventilation. Energy and Buildings, 68, 515-531.

40. Melikov, A. K. (2004), Personalized ventilation. Indoor Air, 14: 157-167.

41. Melikov, A., Bolashikov, Z. D., \& Georgiev, E. (2011). Novel ventilation strategy for reducing the risk of airborne cross infection in hospital rooms. Proceedings of Indoor Air 2011, 1037.

42. Yang, J., Kaczmarczyk, J., Melikov, A. K., \& Fanger, P. O. (2003). The impact of a personalized ventilation system on indoor air quality at different levels of room air temperature. In 7 th International Conference on Healthy Buildings 2003 (pp. 345-350). Healthy Buildings 2003.

43. Pan, C. S., Chiang, H. C., Yen, M. C., \& Wang, C. C. (2005). Thermal comfort and energy saving of a personalized PFCU air-conditioning system. Energy and Buildings, 37(5), 443-449.

44. Zhou, W., Tham, K.W. Performance of a desktopmounted air terminal device for personalized ventilation system (2005) Proceedings of CLIMA 2005, pp. 370-376.

45. Sekhar, S., Maheswaran, C., Nan, G., Cheong, D., Tham, K. W., Melikov, A. K., \& Fanger, P. O. (2003). Energy efficiency potential of personalized ventilation system in the tropics. In 7th International Conference on Healthy Buildings 2003 (pp. 686689). University of Singapore, Department of Buildings.

46. Sun, W., Tham, K. W., Zhou, W., \& Gong, N. (2007). Thermal performance of a personalized ventilation air terminal device at two different turbulence intensities. Building and environment, 42(12), 39743983.

47. Tham, K. W., Sekhar, S. C., Cheong, D. K. W., \& Gong, N. (2004). A case study of quantitative energy efficiency of personalized ventilation in the tropics. Proceedings of ROOMVENT 2004, 5-8.

48. Niu, J. L. (2003). Potential IAQ and energy benefits achievable with personalized air supply.

49. Gao, N. P., Niu, J. L., \& Zuo, H. G. (2004). Ventilation efficiency of personalized ventilation: experimental study.

50. Niu, J., Gao, N., Phoebe, M., \& Huigang, Z. (2007). Experimental study on a chair-based personalized ventilation system. Building and Environment, 42(2), 913-925.

51. Gao, N. P., \& Niu, J. L. (2004). Ventilation efficiency of personalized Ventilation: CFD study.

52. Kobayashi, N., \& Chen, Q. (2003). Floor-supply displacement ventilation in a small office. Indoor and Built Environment, 12(4), 281-291.

53. Halvoňová, B., \& Melikov, A. K. (2010). Performance of "ductless" personalized ventilation in conjunction with displacement ventilation: Impact of intake height. Building and Environment, 45(4), 9961005.

54. Cermak, R., Melikov, A. K., Forejt, L., \& Kovar, O. (2006). Performance of personalized ventilation in conjunction with mixing and displacement ventilation. Hvac\&R Research, 12(2), 295-311.

55. Melikov, A., Ivanova, T., \& Stefanova, G. (2012). Seat headrest-incorporated personalized ventilation: Thermal comfort and inhaled air quality. Building and Environment, 47, 100-108.

56. Sekhar, S. C., Gong, N., Tham, K. W., Cheong, K. W., Melikov, A. K., Wyon, D. P., \& Fanger, P. O. (2005). Findings of personalized ventilation studies in a hot and humid climate. HVAC\&R Research, 11(4), 603-620.

57. Yang, B., Sekhar, S. C., \& Melikov, A. K. (2010). Ceiling-mounted personalized ventilation system integrated with a secondary air distribution system-a human response study in hot and humid climate. Indoor Air, 20(4), 309-319.

58. Faulkner, D., Fisk, W. J., \& Sullivan, D. P. (1993). Indoor air flow and pollutant removal in a room with desk-top ventilation.

59. Kaczmarczyk, J., Melikov, A., Bolashikov, Z., Nikolaev, L., \& Fanger, P. O. (2006). Human response to five designs of personalized ventilation. HVAC\&R Research, 12(2), 367-384. 
60. Li, R., Sekhar, S. C., \& Melikov, A. K. (2010). Thermal comfort and IAQ assessment of under-floor air distribution system integrated with personalized ventilation in hot and humid climate. Building and Environment, 45(9), 1906-1913.

61. Kaczmarczyk, J., Melikov, A., \& Sliva, D. (2010). Effect of warm air supplied facially on occupants' comfort. Building and Environment, 45(4), 848-855.

62. Melikov, A. K., Skwarczynski, M. A., Kaczmarczyk, J., \& Zabecky, J. (2013). Use of personalized ventilation for improving health, comfort, and performance at high room temperature and humidity. Indoor Air, 23(3), 250-263.

63. Melikov, A. K., \& Kaczmarczyk, J. (2012). Air movement and perceived air quality. Building and Environment, 47, 400-409.

64. Lyubenova, V. S., Holsøe, J. W., \& Melikov, A. K. (2011). Potential energy savings with personalized ventilation coupled with passive chilled beams. In Roomvent-12th International Conference on Air Distribution in Rooms.

65. Kaczmarczyk, J., Zeng, Q., Melikov, A., \& Fanger, P. O. (2002). The effect of a personalized ventilation system on perceived air quality and SBS symptoms. Proceedings of indoor air, 4, 1042-1047.

66. Faulkner, D., Fisk, W. J., Sullivan, D. P., \& Wyon, D. P. (1999). Ventilation efficiencies of deskmounted task/ambient conditioning systems. Indoor air, 9(4), 273-281.

67. Melikov, A. K., Cermak, R., Kovar, O., Forejt, L., Wai, T. K., Sakhar, S. C., \& Cheong, D. (2003). Impact of airflow interaction on inhaled air quality and transport of contaminants in rooms with personalized and total volume ventilation. In 7 th International Conference on Healthy Buildings 2003. Natiol University of Singapore, Department of Buildings.

68. Zuo, H. G., Niu, J. L., \& Chan, W. T. (2002). Experimental study of facial air supply method for the reduction of pollutant exposure. Proceedings of Indoor Air, 1090-1095.

69. Cermak, R., \& Melikov, A. K. (2003). Performance of personalized ventilation in a room with an underfloor air distribution system: transport of contaminants between occupants. In 7th International Conference on Healthy Buildings 2003 (pp. 486491). NUS Press Pte Ltd.

70. Cermak, R., \& Melikov, A. K. (2004). Transmission of exhaled air between occupants in rooms with personalized and underfloor ventilation. Procedings of Roomvent 2004.

71. Cermak, R., Melikov, A. K., Forejt, L., \& Kovar, O. (2004). Distribution of contaminants in the occupied zone of a room with personalized and displacement ventilation. In 9th International Conference on Air Distribution in Rooms. University of Coimbra.

72. Bolashikov, Z. D., Nikolaev, L., Melikov, A. K., Kaczmarczyk, J., \& Fanger, P. O. (2003).
Personalized ventilation: air terminal devices with high efficiency. In 7th International Conference on Healthy Buildings 2003 (pp. 850-855). Healthy Buildings 2003.

73. Tsuzuki, K., Arens, E., Bauman, F., \& Wyon, D. (1999). Individual thermal comfort control with deskmounted and floor-mounted task/ambient conditioning (TAC) systems.

74. Forejt, L., Melikov, A. K., Cermak, R., \& Kovar, O. (2004). Thermal comfort of seated occupants in rooms with personalized ventilation combined with mixing or displacement ventilation. Procedings of Roomvent2004.

75. Veselý, M., \& Zeiler, W. (2014). Personalized conditioning and its impact on thermal comfort and energy performance-A review. Renewable and Sustainable Energy Reviews, 34, 401-408.

76. Halvoňová, B., \& Melikov, A. K. (2010). Performance of "ductless" personalized ventilation in conjunction with displacement ventilation: Impact of disturbances due to walking person (s). Building and Environment, 45(2), 427-436.

77. Halvonová, B., \& Melikov, A. K. (2010). Performance of ductless personalized ventilation in conjunction with displacement ventilation: impact of workstations layout and partitions. HVAC\&R Research, 16(1), 75-94.

78. Zeng, Q., Kaczmarczyk, J., Melikov, A. K., \& Fanger, P. O. (2002). Perceived air quality and thermal sensation with personalised ventilation system. In Roomvent-8th International Conference on Air Distribution in Rooms (pp. 61-64).

79. Kaczmarczyk, J., Zheng, Q., Melikov, A. K., \& Fanger, P. O. (2002). Individual control and people's preferences in experiments with personalized ventilation system. In Roomvent-8th International Conference on Air Distribution in Rooms (pp. 5760).

80. Yang, J., Melikov, A. K., Fanger, P. O., Li, X., \& Yan, Q. (2002). Impact of personalized ventilation on human response: comparison between constant and fluctuating airflows under warm condition. In Roomvent-8th International Conference on Air Distribution in Rooms (pp. 305-308).

81. Sun, W., Cheong, K. W. D., \& Melikov, A. K. (2012). Subjective study of thermal acceptability of novel enhanced displacement ventilation system and implication of occupants' personal control. Building and Environment, 57, 49-57.

82. Gao, N., \& Niu, J. (2004). CFD study on microenvironment around human body and personalized ventilation. Building and Environment, 39(7), 795805.

83. de Dear, R. J., Arens, E., Hui, Z., \& Oguro, M. (1997). Convective and radiative heat transfer coefficients for individual human body segments. International Journal of Biometeorology, 40(3), 141 156. 
84. Faulkner, D., Fisk, W. J., Sullivan, D. P., \& Lee, S. M. (2002). Ventilation efficiencies of a desk-edgemounted task ventilation system.

85. Schiavon, S., \& Melikov, A. K. (2009). Energysaving strategies with personalized ventilation in cold climates. Energy and Buildings, 41(5), 543-550.

86. Schiavon, S., Melikov, A. K., \& Sekhar, C. (2010). Energy analysis of the personalized ventilation system in hot and humid climates. Energy and buildings, 42(5), 699-707.

87. Conceição, E. Z., Lúcio, M. M. J., Rosa, S. P., Custódio, A. L., Andrade, R. L., \& Meira, M. J. (2010). Evaluation of comfort level in desks equipped with two personalized ventilation systems in slightly warm environments. Building and Environment, 45(3), 601-609.

88. Kaczmarczyk, J., Melikov, A. K., Bolashikov, Z., Nikolaev, L., \& Fanger, P. O. (2004). Thermal sensation and comfort with five different air terminal devices for personalized ventilation. In Manuel Carlos Gameiro da Silva Roomvent2004.

89. Van Hoof, J. (2008), Forty years of Fanger's model of thermal comfort: comfort for all?. Indoor Air, 18: $182-201$. 